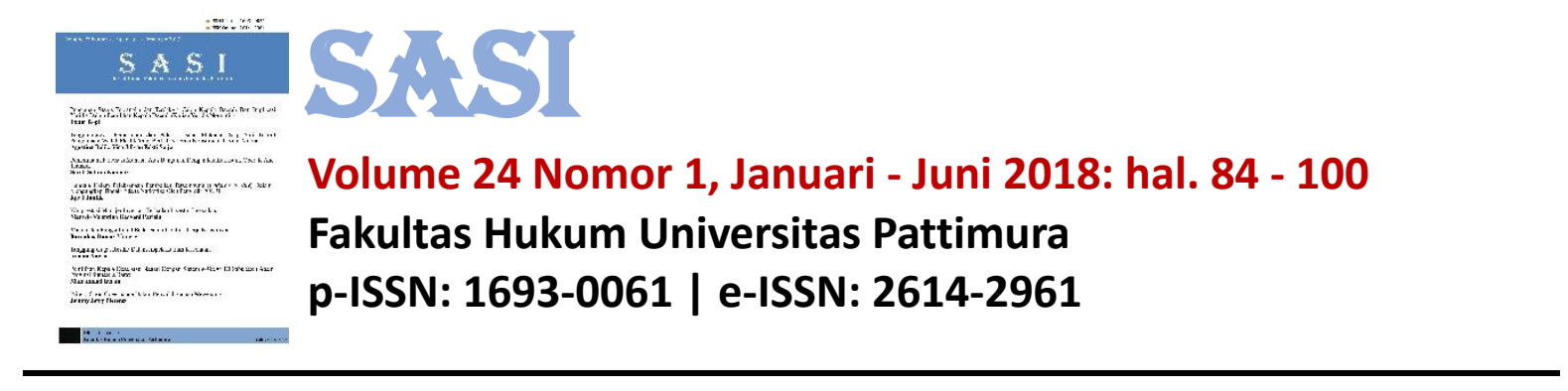

\title{
Tinjauan Eksekusi Putusan Sela Dalam Bentuk Schorsing Pada Pengadilan Tata Usaha Negara
}

\author{
Dezonda Rosiana Pattipawae \\ Program Doktor Ilmu Hukum Pascasarjana Universitas Borobudur, Jakarta, Indonesia \\ E-mail: pattipawaeonda@gmail.com
}

\begin{abstract}
The postponement of a State Administrative Decision which becomes the object of the dispute may be granted, since there is still a continuous factual action to be taken, namely the appointment of a definitive Regional Secretary, the inauguration or handover of the position of the dismissed Regional Secretary to the appointed Secretary of the Region whose contents as statements (declarations) of submission of all duties, powers and duties.

Decree of the Governor of Maluku Number: 125.a Year 2014 dated May 20, 2014 concerning the Transfer of Civil Servants, on behalf of Kapressy Charles, SH. MSi, NIP: 195609111986031009 from Southwest Maluku District in Tiakur to the Government of Povinsi Maluku in Ambon, so Kapressy Charles, SH. Msi, felt his interest was damaged by the decision issued by the Governor of Maluku as the State Administration Officer. Therefore the concerned filed a lawsuit to the State Administrative Court of Ambon with Case No. 23/G/2014/PTUN.ABN, concerned requested to carry out the postponement of the transfer from the Government of the Southwest Maluku District to the Government of Maluku Province in due to the contradiction of the principles general good governance or prevailing laws and regulations.
\end{abstract}

Keywords: Execution, Interlocutor, Schorsing

\section{A. PENDAhULUAN.}

Peradilan Tata Usaha Negara sebagai salah satu subsistim dari sistim pengawasan yang dilakukan terhadap tindakan Pemerintah / Pejabat Tata Usaha Negara dalam rangka menegakan aturan hukum dan asas-asas penyelenggaraan Pemerintahan agar Pemerintah / Pejabat Tata Usaha Negara dalam melakukan tindakan-tindakan terkait dengan penyelenggaraan fungsi Pemerintahan tidak merugikan masyarakat. Semakin meningkatnya kualitas urusan Pemerintahan yang diselenggaraan oleh Pemerintah Pusat maupun Pemerintah di Daerah tentunya berpotensi pada terjadinya tindakan - tindakan yang merugikan kepentingan masyarakat, bila Badan atau Pejabat Tata Usaha Negara (yang berada di pusat maupun daerah) dalam melakukan tindakan Pemerintahan tidak berdasar atau melanggar aturan hukum dan asas - asas penyelenggaraan 
pemerintahan. Oleh sebab itu, kehadiran Peradilan Tata Usaha Negara adalah untuk melakukan tindakan pengawasan yudisial terhadap tindakan Pemerintahan baik yang dilakukan oleh Badan atau Pejabat Tata Usaha Negara baik di pusat maupun daerah tersebut. Masyarakat (orang atau badan hukum perdata) yang merasa dirugikan akibat tindakan Badan atau Pejabat Tata Usaha Negara menjadikan Peradilan Tata Usaha Negara untuk mengawasi tindakan Badan atau Pejabat Tata Usaha Negara dalam bentuk pengujian sah tidaknya Keputusan Tata Usaha Negara dari tindakan Badan atau Pejabat Tata Usaha Negara tersebut melalui gugatan kepada Pengadilan Tata Usaha Negara, sebagaimana ditetapkan dalam ketentuan Pasal 53 Undang-Undang Nomor 5 Tahun 1986 yang telah dirubah terakhir dengan Undang-Uandng Nomor 51 Tahun 2009 tentang Peradilan Tata Usaha Negara.

Pengujian oleh Peradilan Tata Usaha Negara terhadap tindakan Badan atau Pejabat Tata Usaha Negara dapat berupa tindakan mengeluarkan Keputusan Tata Usaha Negara atau tidak mengeluarkan Keputusan Tata Usaha Negara yang dianggap bertentangan dengan peraturan perundang-undangan dan/atau Asas - Asas Umum Penyelenggaraan Pemerintahan. Pengujian oleh Pengadilan Tata Usaha Negara disamping untuk melindungi kepentingan orang atau badan hukum perdata (masyarakat), juga sebagai bentuk koreksi terhadap tindakan Badan atau Pejabat Tata Usaha Negara dalam menyelenggarakan fungsi Pemerintahan.

Keputusan Tata Usaha Negara adalah Suatu penetapan tertulis yang dikeluarkan oleh Badan atau Pejabat Tata Usaha Negara yang berisi tindakan hukum Tata Usaha Negara berdasarkan peraturan perundang-undangan yang berlaku, yang bersifat kongkrit, individu, dan final, yang menimbulkan akibat hukum bagi seseorang atau badan hukum perdata
Oleh karena itu, orang atau badan hukum perdata yang merasa dirugikan akibat tindakan Badan atau Pejabat Tata Usaha Negara yang mengeluarkan atau tidak mengeluarkan Keputusan Tata Usaha Negara, menjadikan Peradilan Tata Usaha Negara sebagai sarana untuk melakukan pengawasan terhadap tindakan Badan atau Pejabat Tata Usaha Negara tersebut dalam bentuk pengujian terhadap Keputusan Tata Usaha Negara melalui gugatan yang diajukan ke Peradilan Tata Usaha Negara guna mencari keadilan dan kepastian hukum atas tindakan Badan atau Pejabat Tata Usaha Negara tersebut. Gugatan adalah permohonan yang berisi tuntutan terhadap Badan atau Pejabat Tata Usaha Negara dan diajukan ke Pengadilan untuk mendapatkan Putusan

Menurut Supandi penundaan pelaksanaan Keputusan Tata Usaha Negara dikeluarkan oleh Pengadilan Tata Usaha Negara, harus dijabarkan secara sangat hati-hati karena semata - mata hanya untuk memberikan kualitas keseimbangan perlindungan kepentingan umum dengan kepentingan individu warganegara (Penggugat). Namun, manakala dalam rangka melindungi kepentingan individu warganegara (Penggugat) tersebut berakibat terlantarnya kepentingan umum, maka Pengadilan (hakim) wajib mengutamakan kepentingan umum. ${ }^{1}$

Menurut Soemaryo bahwa permohonan Penggugat untuk dapat dikeluarkan penetapan penundaan harus dapat menguraikan secara jelas tentang dua hal : ${ }^{2}$

1. Terdapat keadaan yang mendesak yang mengakibatkan kepentingan Penggugat sangat dirugikan, jika

${ }^{1}$ Supandi, 2002, Ganti Rugi Akibat Tindakan Pejabat Pemerintah Dalam RUU Administrasi Pemerintahan Dan Prospek Peradilan Tata Usaha Negara, Sofemdia, Medan, h, 317-318.

2 Soemaryo, 2009, Tuntunan Praktek Beracara Di Peradilan Tata Usaha Negara, Primamedia Pustaka, Jakarta, h, 92. 
Keputusan Tata Usaha Negara yang digugat dilaksanakan.

2. Tidak terdapatnya kepentingan umum yang menjadi dasar dikeluarkannya Keputusan Tata Usaha Negara yang digugat tersebut.

Permohonan penundaan dapat diajukan sekaligus dalam surat gugatan atau terpisah tetapi diajukan bersamaan dengan gugatan atau diajukan selambat-lambatnya pada waktu replik. Pada keadaan atau alasan yang mendesak sebagaimana disebutkan diatas maka Hakim segera mengambil sikap untuk melakukan penundaan pelaksanaan terhadap Keputusan Tata Usaha Negara yang digugat. Putusan Hakim mengenai penundaan tersebut dalam bentuk penetapan Hakim, yang daya lakunya mengikat sampai dengan adanya Putusan pokok sengketanya mempunyai kekuatan hukum tetap. Putusan Hakim tersebut merupakan Putusan sementara dalam bentuk Putusan Sela, yang sifatnya bukan Putusan Akhir dalam proses pemeriksaan terhadap objek sengketa. ${ }^{3}$

Di dalam rumusan norma Pasal 67 ayat (4) Undang-Undang Nomor 5 Tahun 1986 dan Penjelasan Pasal 67 huruf a dan b, terdapat konsep-konsep hukum yang merupakan syarat untuk dikabulkannya permohonan penundaan, akan tetapi konsep tersebut sifatnya terbuka untuk diberi makna seperti :

1. Konsep keadaan mendesak;

2. Konsep kerugian; dan

3. Kepentingan umum dalam rangka pembangunan.

Konsep-konsep tersebut terbuka untuk diberi makna, oleh karena Undang-Undang itu sendiri tidak memberi pengertian secara ontentik di dalam Pengertian Umum maupun di dalam Penjelasan Umum dan Penjelasan

3 Marbun S. F, 2003, Peradilan Hukum Administrasi dan Upaya Administrasi di Indonesia, UII - Press, Jogjakarta, h, 259.
Pasal Undang-Undang tersebut. H. L. A. Hart mengatakan, sering sekali penggunaan sebuah istilah biasa, atau bahkan istilah teknis, bersifat cukup "terbuka" dalam pengertian bahwa di sana tidak ada halangan untuk memperluas istilah sampai pada kasus-kasus tertentu dimana hanya ada sebagian ciri yang biasanya hadir bersama 4 dalam menghadapi konsep - konsep hukum yang sifatnya terbuka, disinilah peran hakim untuk melakukan interpretasi. ${ }^{5}$

Permasalahan yang kemudian muncul dalam praktek kadangkala berdasarkan fakta hukum yang ada Hakim berpendapat Keputusan Tata Usaha Negara yang digugat di Pengadilan jika dikaitkan dengan syarat untuk dikabulkan penundaan pelaksanaannya telah memenuhi ketentuan seperti dimaksud dalam Pasal 67 Undang-Undang Nomor 5 Tahun 1986 yakni kepentingan Penggugat sangat dirugikan dan tidak seimbang dibandingkan dengan manfaat yang akan dilindungi jika Keputusan Tata Usaha Negara tersebut tetap dilaksanakan dan tidak ada kepentingan umum dalam rangka pembangunan yang terkait dengan Keputusan Tata Usaha Negara yang digugat tersebut, akan tetapi dikaitkan dengan Petunjuk Pelaksanaan Nomor 1 Tahun 2005 khususnya pada point ke-4 yang mensyaratkan bahwa perbuatan faktual yang menjadi isi dalam Surat Keputusan Tata Usaha Negara yang dimohonkan penundaan pelaksanaannya belum dilaksanakan ternyata pada saat diperiksa di Pengadilan sudah dilakukan dan dikarenakan perbuatan faktualnya bersifat terus-menerus (bukan termasuk jenis perbuatan yang pelaksanaannya

${ }^{4}$ H.L.A. Hart, 2009, Konsep Hukum (The Concept Of Law), Penerjemah M. Khoizin, Nusa Media, Bandung, h, $23-24$.

5 Sjahran Basah, 2002, Perlindungan Hukum terhadap sikap-tindak Administrasi Negara, cetakan II, Alumni, Bandung, h, 34 
dilakukan sekali saja dan langsung selesai, seperti perbuatan pembongkaran rumah) prosesnya tetap berjalan sampai dengan tenggang waktu pelaksanaan yang ditetapkan di dalam Keputusan Tata Usaha Negara tersebut berakhir. ${ }^{6}$

Putusan Sela adalah Putusan yang dijatuhkan masih dalam proses pemeriksaan perkara dengan tujuan untuk memperlancar jalannya pemeriksaan. Putusan Sela tidak mengakhiri pemeriksaan, tetapi akan berpengaruh terhadap arah dan jalannya pemeriksaan, namun Putusan Sela dituangkan dalam bentuk penetapan yang terpisah dengan Putusan Akhir, tujuannya adalah untuk menghindari agar penetapan penundaan tidak menempel terus pada pokok perkaranya sampai dengan Putusan berkekuatan hukum tetap.

Surat Keputusan Gubernur Maluku Nomor : 125.a Tahun 2014 tanggal 20 Mei 2014 tentang Pemindahan Pegawai Negeri Sipil, atas nama Kapressy Charles, SH. Msi, NIP : 195609111986031009 dari Kabupaten Maluku Barat Daya di Tiakur ke Pemerintah Povinsi Maluku di Ambon ${ }^{7}$, sehingga Kapressy Charles, SH. Msi, merasa kepentingannya dirugian akibat keputusan yang dikeluarkan oleh Gubernur Maluku selaku Pejabat Tata Usaha Negara. Oleh karenanya yang bersangkutan mengajukan Gugatan ke Pengadilan Tata Usaha Negara Ambon dengan Nomor Perkara : 23/G/2014/PTUN.ABN, yang bersangkutan memohon untuk melaksanakan penundaan pemindahan dari Pemerintah Kabupaten Maluku Barat

6 Dani Elpah, 2011, Penundaan Pelaksanaan Keputusan Tata Usaha Negara, disampaikan pada Pelatihan Hakim Peradilan Tata Usaha Negara, Diklat Kumdil MA RI, Megamendung, h, 23

7 Surat Keputusan Gubernur Maluku Nomor : 125.a Tahun 2014 tanggal 20 Mei 2014 tentang Pemindahan Pegawai Negeri Sipil, atas nama Kapressy Charles, SH. Msi, NIP : 19560911 1986031009 dari Kabupaten Maluku Barat Daya di Tiakur ke Pemerintah Povinsi Maluku di Ambon
Daya ke Pemerintah Provinsi Maluku di karenakan bertentangan dengan asas-asas umum pemerintahan yang baik ataupun peraturan perundang-undangan yang berlaku. Dalam permohonan penundaan tersebut Majelis Hakim Pengadilan Tata Usaha Negara yang memeriksa, mengadili dan memutuskan perkara tersebut mengabulkan permohonan Penundaan dan memerintahkan kepada Gubernur Maluku selaku Pejabat Tata Usaha Negara untuk menunda pelaksanaan dan tindak lanjut Keputusan Tata Usaha Negara berupa Surat Keputusan Gubernur Maluku Nomor : 125. a Tahun 2014, tanggal 20 Mei 2014 tentang Pemindahan Pegawai Negeri Sipil atas nama Kapressy Charles, SH, M.Si， NIP : 195609111986031009 Pembina Utama Madya (IV/d) dari Pemerintah Kabupaten Maluku Barat Daya di Tiakur ke Pemerintah Provinsi Maluku di Ambon, sampai putusan sengketa ini mempunyai kekuatan hukum tetap, kecuali ada Penetapan lain yang menyatakan sebaliknya, memerintahkan kepada Panitera Pengadilan Tata Usaha Negara Ambon untuk menyampaikan salinan Penetapan ini kepada para pihak untuk segera dipatuhi dan dilaksanakan.

Terhadap Putusan Sela tersebut harus dilaksanakan atau menjadi kewajiban bagi Tergugat untuk melaksanakannya meskipun belum ada Putusan Akhir yang sifatnya mengakhiri sengketa tersebut. Dengan demikian Putusan Sela tersebut mempunyai kekuatan eksekutorial.

Dari uraian Pada latar belakang tersebut, maka yang menjadi permasalahan dalam tulisan ini adalah : "Bagaimana Kekuatan Eksekutorial Putusan Sela Dalam Bentuk Schorsing Pada Pengadilan Tata Usaha Negara"

\section{B. PEMBAHASAN}

\section{Kekuatan Eksekutorial Putusan Sela}


Pendekatan yang akan digunakan oleh Majelis Hakim Pengadilan Tata Usaha Negara Ambon dalam menilai permohonan penundaan pelaksanaan Keputusan Tata Usaha Negara, yaitu dengan menggunakan pendekatan statute approach (pendekatan peraturan perundang-undangan) dalam hal ini Pasal 67 Undang-Undang Nomor 5 Tahun 1986 tentang Peradilan Tata Usaha Negara Jo Undang-Undang Nomor 9 Tahun 2004 tentang Perubahan atas Undang-Undang Nomor 5 Tahun 1986 Jo Undang-Undang Nomor 51 Tahun 2009 tentang Perubahan Kedua Atas Undang-Undang Nomor 5 Tahun 1986 tentang Peradilan Tata Usaha Negara.

Salah satu sumber Hukum Administrasi adalah kebiasaan-kebiasan yang dipraktekkan oleh pemerintah, merupakan suatu konvensi atau kebiasaan-kebiasaan yang secara terus menerus dilakukan dalam pengangkatan seorang pejabat, yaitu terdapat perbuatan-perbuatan faktual yang dilakukan antara lain, berupa pelantikan dan serah terima jabatan sebagai suatu perbuatan faktual yang berlanjut. Berdasarkan konvensi atau kebiasaan dan asas acontario actus, maka menurut Majelis Hakim pelantikan dan serah terima jabatan merupakan suatu perbuatan faktual yang semestinya dilakukan. Berdasarkan asas acontrario actus, manakala terjadi pergantian jabatan sebagai Sekretaris Daerah, maka terdapat adanya serah terima jabatan dari Sekretaris Daerah yang lama ke Sekretaris Daerah yang baru sehingga hendaknya, diperlakukan sama ketika Penggugat diberhentikan. ${ }^{8}$ Dengan memperhatikan masa jabatan yang disebutkan secara jelas dan tegas di dalam Keputusan Bupati Maluku Barat Daya Nomor : 800-204 Tahun 2011, tanggal 06 September 2011 Tentang

8 Pertimbangan Penetapan Penundaan Majelis Hakim Pengadilan Tata Usaha Negara Dalam Perkara Nomor 23/G/2014/PTUN.ABN, h, 5
Perpanjangan Pertama Kali Batas Usia Pensiun (BUP) Pegawai Negeri Sipil Di Lingkungan Pemerintah Daerah Maluku Barat Daya ${ }^{9}$ tersebut, maka masa jabatan Penggugat berakhir pada tanggal 10 September 2014. Akan tetapi dengan dikeluarkannya obyek sengketa, yaitu Keputusan Gubernur Maluku Nomor : 125.a Tahun 2014, tanggal 20 Mei 2014 Tentang Pemindahan Pegawai Negeri Sipil, masa jabatan Penggugat terpangkas lebih kurang 4 (empat) bulan dari keadaan yang normal.

Tindak lanjut atas keluarnya obyek sengketa, yaitu Keputusan Gubernur Maluku Nomor : 125. a Tahun 2014, tanggal 20 Mei 2014 tentang Pemindahan Pegawai Negeri Sipil atas nama KAPRESSY CHARLES, SH, MSi, NIP : 195609111986031009 Pembina Utama Madya (IV/d) dari Pemerintah Kabupaten Maluku Barat Daya di Tiakur ke Pemerintah Provinsi Maluku di Ambon, adalah telah ditunjuk Plt. Sekretaris Daerah Kabupaten Maluku Barat Daya, yaitu Drs. Joseph Domlay, sedangkan berkaitan dengan Pengangkatan Sekretaris Daerah yang defenitif, serah terima jabatan dan Pelantikan belum dilakukan sampai dengan saat ini, sesuai keterangan Kuasa Tergugat, pada persidangan tanggal 21 Juli 2014 . Seiring dengan berjalannya waktu, oleh karena sengketa Tata Usaha Negara ini diperiksa dengan Acara Biasa di Pengadilan Tingkat pertama, dan disisi lain sistem peradilan di Indonesia terbuka untuk diajukan upaya hukum kepada lembaga peradilan yang lebih tinggi, bisa terjadi akan memakan waktu melebihi dari sisa waktu masa jabatan Penggugat, sekiranya gugatan Penggugat dapat dibuktikan dan tidak dilakukan penundaan pelaksanaan terhadap obyek sengketa, maka

9 Keputusan Bupati Maluku Barat Daya Nomor : 800-204 Tahun 2011, tanggal 06 September 2011 Tentang Perpanjangan Pertama Kali Batas Usia Pensiun (BUP) Pegawai Negeri Sipil Di Lingkungan Pemerintah Daerah Maluku Barat Daya 
pemulihan terhadap keadaan posisi semula bagi Penggugat setelah putusan terhadap sengketa Tata Usaha Negara ini memperoleh kekuatan hukum tetap tidak mungkin dilakukan, bila hal ini terjadi, maka bagi yustisiabelen (pencari keadilan) tidak ada manfaatnya. Akan tetapi manakala kepentingan yang mendesak tidak ada lagi dan sekiranya gugatan penggugat tidak diterima atau ditolak maka terhadap penundaan pelaksanaan Keputusan Tata Usaha Negara obyek sengketa harus juga dicabut sehingga tidak terjadi penyanderaan.

Majelis Hakim Pengadilan Tata Usaha Negara Ambon berpendapat syarat dapat dikabulkannya permohonan penundaan sebagaimana dimaksud di dalam Pasal 67 ayat (4) huruf a telah terpenuhi. Majelis Hakim tidak melihat adanya kepentingan umum dalam rangka pembangunan dalam perkara a quo yang mengharuskan dilaksanakannya

Keputusan Tata Usaha Negara yang menjadi obyek sengketa tersebut . ${ }^{10}$

Penundaan Keputusan Tata Usaha Negara yang menjadi obyek sengketa dapat dikabulkan, oleh karena masih adanya tindakan faktual yang berlanjut yang harus dilakukan, yaitu Pengangkatan Sekretaris Daerah yang defenitif, pelantikan ataupun serah terima jabatan dari Sekretaris Daerah yang diberhentikan kepada Sekretaris Daerah yang diangkat yang isinya sebagai suatu pernyataan (deklaratur) penyerahan segala tugas, wewenang dan kewajiban.

Majelis Hakim juga memperhatikan dan mengambilnya sebagai pertimbangan tentang sifat Penetapan Pengadilan Tata Usaha Negara yang berlaku secara “ Erga Omnes “, yaitu mengikat dan berlaku secara umum terhadap pihak-pihak yang terkait dengan pelaksanaan Surat Keputusan Objek Sengketa a quo serta adanya Surat Menteri Pendayagunaan Aparatur Negara

10 Pertimbangan Penetapan Penundaan Majelis Hakim Pengadilan Tata Usaha Negara, $O p$ Cit, h, 7 tanggal $29 \quad$ Mei 1991

Nomor : B-47/I/1991 perihal pelaksanaan putusan Pengadilan Tata Usaha Negara yang ditujukan kepada para Pejabat Tinggi Negara, antara lain kepada para Gubernur seluruh Indonesia, yang mencantumkan pada pokoknya bahwa Pejabat Tata Usaha Negara yang digugat hendaknya membantu kelancaran proses penyelesaian perkara gugatan dan melaksanakan putusan dengan sebaik-baiknya ${ }^{11}$ dan Surat Menteri Pendayagunaan Aparatur Negara tanggal $28 \quad$ Agustus 2004 Nomor : SE/24/M.PAN/8/2004 Perihal Pelaksanaan Putusan Pengadilan Tata Usaha Negara ${ }^{12}$

Pelanggaran terhadap Penetapan ini akan menjadi tanggung jawab sepenuhnya baik secara yuridis maupun administratif terhadap pihak yang melanggarnya. Mengingat ketentuan dalam Undang-Undang Nomor 5 Tahun 1986 Tentang Peradilan Tata Usaha Negara sebagaimana telah dirubah oleh Undang-Undang Nomor 9 Tahun 2004 dan Undang-Undang Nomor 51 Tahun 2009 serta ketentuan hukum lain yang bersangkutan

\section{Putusan Pengadilan Tata Usaha Negara Terhadap Putusan Sela}

Objek sengketa dalam perkara ini adalah Surat Keputusan Gubernur Maluku Nomor : 125.a Tahun 2014 tanggal 20 Mei 2014 tentang Pemindahan Pegawai Negeri Sipil atas nama Sdr. Kapressy Charles, SH, M.Si NIP.19560911 $198603 \quad 1009$ Pembina

11 Surat Menteri Pendayagunaan Aparatur Negara tanggal $29 \quad$ Mei 1991 Nomor : B-47/I/1991 perihal pelaksanaan putusan Pengadilan Tata Usaha Negara yang ditujukan kepada para Pejabat Tinggi Negara, antara lain kepada para Gubernur seluruh Indonesia.

12 Surat Menteri Pendayagunaan Aparatur Negara tanggal 28 Agustus 2004 Nomor : SE/24/M.PAN/8/2004 Perihal Pelaksanaan Putusan Pengadilan Tata Usaha Negara. 
Utama Madaya (IV/d) dari Pemerintah Kabupaten Maluku Barat Daya di Tiakur ke Pemerintah Provinsi Maluku di Ambon Drs. Joseph Domlay selaku PLT Sekretaris Daerah Maluku Barat Daya telah dipanggil secara patut oleh Pengadilan Tata Usaha Negara Ambon sesuai Surat Panggilan Nomor : W4-TUN3/532/H.01.03/VI/2014, tanggal 25 Juni 2014 13 , Nomor : W4-TUN3/595/H.01.03/VII/2014, tanggal 07 Juli $2014^{14}$ dan Nomor : W4-TUN3/616/H.01.03/VII/2014, tanggal 14 Juli $2014^{15}$, namun yang bersangkutan tidak pernah memenuhi panggilan Pengadilan, dengan demikian Drs. Joseph Domlay yang merupakan pihak ketiga dalam perkara a quo dianggap tidak menggunakan haknya untuk menjadi pihak dalam perkara $a$ quo.

Gugatan Penggugat tertanggal 12 Juni 2014 yang didaftar di Kepaniteraan Pengadilan Tata Usaha Negara Ambon pada tanggal 12 Juni 2014 dan telah diperbaiki pada tanggal 7 Juli 2014, Tergugat telah mengajukan Jawaban tertanggal 21 Juli 2014 dimana di dalamnya tidak memuat Eksepsi dan langsung pada Pokok sengketa. Majelis Hakim terlebih dahulu akan mempertimbangkan apakah pengajuan Gugatan dalam sengketa ini telah memenuhi persyaratan formal Gugatan terkait 1). apakah Objectum litis merupakan sebuah Keputusan Tata Usaha

13 Surat Panggilan I Nomor W4-TUN3/532/H.01.03/VI/2014, tanggal 25 Juni 2014, Sebagai Pihak Ketiga Dalam Perkara Nomor Nomor 23/G/2014/PTUN.ABN di Pengadilan Tata Usaha Negara Ambon

14 Surat Panggilan II Nomor W4-TUN3/595/H.01.03/VII/2014, tanggal 07 Juli 2014, Sebagai Pihak Ketiga Dalam Perkara Nomor Nomor 23/G/2014/PTUN.ABN di Pengadilan Tata Usaha Negara Ambon

15 Surat Panggilan III Nomor : W4-TUN3/616/H.01.03/VII/2014, tanggal 14 Juli 2014, Sebagai Pihak Ketiga Dalam Perkara Nomor Nomor 23/G/2014/PTUN.ABN di Pengadilan Tata Usaha Negara Ambon
Negara, 2). apakah Penggugat mempunyai kepentingan dalam mengajukan Gugatan a quo dan, 3). apakah Gugatan Penggugat diajukan masih dalam tenggang waktu yang ditentukan, sehingga Pengadilan Tata Usaha Negara berwenang untuk memeriksa, memutus dan menyelesaikan sengketa a quo.

Keputusan Tata Usaha Negara beradasarkan Pasal 1 angka 9 Undang-Undang Nomor 51 Tahun 2009 adalah suatu penetapan tertulis yang dikeluarkan oleh badan atau pejabat tata usaha negara yang berisi tindakan hukum tata usaha negara yang berdasarkan peraturan perundang-undangan yang berlaku, yang bersifat konkret, individual, dan final, yang menimbulkan akibat hukum bagi seseorang atau badan hukum perdata. Syarat suatu keputusan dapat dikatakan sebagai Keputusan Tata Usaha Negara yang menjadi objek sengketa dalam Peradilan Tata Usaha Negara sebagai berikut :

a. Konkrit yakni objek yang diputuskan dalam Keputusan Tata Usaha Negara itu tidak abstrak tetapi berwujud tertentu atau dapat ditentukan. Dalam hal ini Keputusan objek sengketa, yang diterbitkan oleh Tergugat termasuk dalam pengertian konkrit karena objek yang diputuskan dalam Keputusan Tata Usaha Negara tersebut tidak abstrak tetapi berwujud yaitu mengenai pemindahan yang ditujukan kepada Penggugat untuk menjadi Pegawai Negeri Sipil pada Pemerintah Provinsi Maluku di Ambon

b. Individual yakni Keputusan Tata Usaha Negara itu tidak ditujukan untuk umum tetapi tertentu baik alamat maupun hal yang dituju. Dalam hal ini Keputusan objek sengketa yang diterbitkan oleh Tergugat ditujukan kepada Sdr. Kapressy Charles, SH, M.Si (Penggugat) sehingga keputusan 
tersebut telah memenuhi unsur individual

c. Final yakni sudah definitif sehingga tidak memerlukan persetujuan dari instansi atasan/instansi lain dan karenanya menimbulkan akibat hukum dengan suatu perubahan dalam suasana hubungan hukum yang telah ada yaitu menimbulkan suatu hak dan kewajiban pada pihak yang bersangkutan serta menentukan posisi hukum dari Penggugat yang terkena keputusan atas tindakan hukum Tergugat yaitu Penggugat yang sebelumnya merupakan Sekretaris Daerah Kabupaten Maluku Barat Daya menjadi tidak menjabat/berhenti sebagai Sekretaris Daerah Kabupaten Maluku Barat Daya.

Pasal 53 ayat (1) Undang-Undang Peradilan Tata Usaha Negara merupakan perwujudan dari asas dalam peradilan tata usaha negara yaitu poin d'interest poin d'action, yang berarti seseorang atau badan hukum perdata untuk dapat mengajukan gugatan harus mempunyai kepentingan yang dirugikan sebagai akibat terbitnya suatu Keputusan Tata Usaha Negara, oleh karena tanpa ada kepentingannya yang dirugikan oleh terbitnya suatu Keputusan Tata Usaha Negara tidak akan melahirkan hak untuk menggugat, gugatan yang diajukan pada Peradilan Tata Usaha Negara haruslah didasarkan pada hubungan sebab-akibat (causalitas) antara Orang atau Badan Hukum Perdata (in casu Penggugat) di satu pihak dengan Badan atau Pejabat Tata Usaha Negara (in casu Tergugat) di pihak lainnya terkait terbitnya Keputusan Tata Usaha Negara (objek sengketa), hubungan causalitas tersebut harus pula menimbulkan kerugian yang nyata khususnya bagi Penggugat, dengan adanya kerugian yang nyata tersebut terdapatlah kepentingan yang menjadi legal standing bagi Orang atau Badan Hukum Perdata (in casu Penggugat) untuk mengajukan gugatan pada Peradilan Tata Usaha Negara.

Berdasarkan Keputusan Gubernur Maluku Nomor: 821.4/3478/M, tanggal 19 Desember 2008 dan Keputusan Bupati Maluku Barat Daya Nomor 800-204 Tahun 2011, tanggal 6 September 2011, tentang Perpanjangan Pertama Kali Batas Usia Pensiun (BUP) Pegawai Negeri Sipil di Lingkungan Pemerintah Kabupaten Maluku Barat Daya, diperoleh fakta hukum bahwa Penggugat merupakan Pegawai Negeri Sipil Daerah pada Pemerintah Kabupaten Maluku Barat Daya yang menjabat sebagai Sekretaris Daerah Maluku Barat Daya eselon II.A serta memperoleh Tunjangan jabatan. Majelis Hakim berpendapat, oleh karena Penggugat merupakan pihak yang dituju langsung dalam objek sengketa yang isinya memindahkan Penggugat tanpa Jabatan pada Pemerintah Provinsi Maluku, maka terdapat hubungan causalitas (sebab-akibat) antara Penggugat dengan Tergugat akibat diterbitkannya objek sengketa yang menimbulkan kerugian yang nyata berupa hilangnya penghasilan yang diperoleh sebelum terbit objek sengketa, sehingga Penggugat memiliki kepentingan dalam mengajukan gugatan sebagaimana ketentuan Pasal 53 ayat (1) Undang-Undang Nomor 9 Tahun 2004. ${ }^{16}$ Majelis Hakim berpendapat permasalahan hukum administrasi yang harus dipertimbangkan adalah apakah dari aspek kewenangan, prosedur dan atau substansi penerbitan objek sengketa a quo telah sesuai dengan peraturan perundang-undangan yang berlaku dan atau tidak melanggar Asas-Asas Umum Pemerintahan yang Baik”. Jika dari salah satu aspek terpenuhi maka sudah cukup beralasan hukum bagi Majelis Hakim untuk menyatakan batal atau tidak sah Keputusan Tata Usaha Negara yang menjadi sengketa dan Majelis Hakim

16 Pertimbangan Putusan Majelis Hakim Pengadilan Tata Usaha Negara Ambon Dalam Perkara Nomor 23/G/2014/PTUN.ABN, h, 23 
hanya akan melakukan pengujian secara Ex-Tunc, yaitu menguji keabsahan objek sengketa menggunakan fakta-fakta hukum sebelum dan pada saat terbitnya objek sengketa serta sesuai dengan kompetensi dan fungsi Peradilan Tata Usaha Negara dalam memberikan pertimbangan terhadap sengketa a quo hanyalah menilai perbedaan pendapat dari segi yuridis mengenai penerapan hukumnya antara Tergugat dalam hal ini Gubernur Maluku dengan Penggugat (Kapressy Charles, SH, M.Si)

Aspek kewenangan yaitu apakah Tergugat memiliki kewenangan untuk menerbitkan objek sengketa quo. Salah satu prinsip negara hukum adalah wetmatigheid van bestuur atau pemerintahan berdasarkan peraturan perundang-undangan, oleh karenanya setiap tindakan hukum pemerintah harus didasarkan pada wewenang yang diberikan oleh peraturan perundang-undangan yang berlaku. Secara yuridis untuk menguji dari aspek kewenangan penerbitan objek sengketa $a$ quo, Majelis Hakim akan merujuk pada ketentuan Pasal 25 ayat (1) dan (2) Undang-undang Nomor 43 Tahun 1999 Tentang Perubahan Atas Undang-Undang Nomor 8 Tahun 1974 Tentang Pokok-Pokok Kepegawaian.

Pasal 17 ayat (1) huruf b Peraturan Pemerintah Nomor 9 Tahun 2003 tentang Wewenang Pengangkatan, Pemindahan dan Pemberhentian Pegawai Negeri Sipil yang mengatur Pejabat Pembina Kepegawaian Daerah Propinsi menetapkan pemindahan b. Pegawai Negeri Sipil Daerah antara Kabupaten/Kota dan Daerah. Setelah mencermati bukti Penggugat berupa Keputusan Gubernur Maluku Nomor : 125.a Tahun 2014, tanggal 20 Mei 2014 tentang Pemindahan Pegawai Negeri Sipil atas nama Sdr. Kapressy Charles, SH, M.Si NIP.19560911 1986031009 Pembina Utama Madaya (IV/d) dari Pemerintah Kabupaten Maluku Barat Daya di Tiakur ke Pemerintah Provinsi
Maluku di Ambon, ditemukan fakta hukum bahwa keputusan a quo ditetapkan oleh Tergugat selaku Pejabat Pembina Kepegawaian Daerah Provinsi dan ditujukan kepada Penggugat selaku Pegawai Negeri Sipil Daerah Kabupaten Maluku Barat Daya, maka Majelis Hakim berkesimpulan secara yuridis dari aspek kewenangan, Tergugat benar berwenang untuk menerbitkan objek sengketa $a$ quo, sehingga dari segi kewenangan Tergugat tidak bertentangan dengan peraturan perundang-undangan yang berlaku. ${ }^{17}$ Mencermati surat keputusan a quo, terdapat tindakan Tergugat yang dilakukan yaitu Pemindahan Penggugat dari Pemerintah Kabupaten Maluku Barat Daya di Tiakur ke Pemerintah Provinsi Maluku di Ambon tanpa jabatan. Tergugat dalam Jawabannya mendalilkan pada pokoknya bahwa Tergugat melakukan pemindahan/mutasi bukan merupakan inisiatif dari Tergugat tetapi usulan dari Pejabat Pembina Kepegawaian Daerah Kabupaten Maluku Barat Daya yakni Bupati Maluku Barat Daya sesuai Surat Nomor : 005/11/2014, tanggal 18 April 2014 perihal Mutasi yang ditujukan kepada Tergugat ${ }^{18}$. Bahwa surat tersebut telah memenuhi persyaratan bahwa sebagai Instansi Induk telah memberikan persetujuan untuk dilakukan mutasi kepada Penggugat

Aspek prosedural yakni pemindahan Pegawai Negeri Sipil antar instansi dilaksanakan atas permintaan dan persetujuan dari Pejabat Pembina Kepegawaian Daerah yang bersangkutans sesuai Pasal 17 ayat (2) Peraturan Pemerintah Nomor 9 Tahun 2003 tentang Wewenang Pengangkatan, Pemindahan dan Pemberhentian Pegawai Negeri Sipil Pasal 17 ayat (2) Peraturan Pemerintah Nomor 9 tahun 2003 diatur bahwa "Penetapan oleh Pejabat Pembina

17 Ibid, h, 28

18 Surat Bupati Maluku Barat Daya Nomor : 005/11/2014, tanggal 18 April 2014 perihal Mutasi yang ditujukan kepada Gubernur Provinsi Maluku 
Kepegawaian Daerah sebagaimana dimaksud dalam Pasal 17 ayat (1) huruf b dilaksanakan atas permintaan dan persetujuan dari Pejabat Pembina Kepegawaian Daerah yang bersangkutan. ${ }^{19}$

Keputusan Kepala Badan Kepegawaian Negara Nomor 13 Tahun 2003 Tentang Petunjuk Teknis Pelaksanaan Peraturan Pemerintah Nomor 9 Tahun 2003 Tentang Wewenang Pengangkatan Pemindahan Dan Pemberhentian Pegawai Negri Sipil pada Sub Bab IV Prosedur angka 3 huruf a. diatur mengenai prosedur perpindahan Antar Instansi sebagai berikut :

Prosedur Perpindahan Pegawai Negeri Sipil antar Instansi dalam rangka usaha pemenuhan kebutuhan dan pendayagunaan tenaga ahli atau untuk kepentingan dinas diatur sebagai berikut :

1) Pejabat Pembina Kepegawaian instansi yang membutuhkan menghubungi secara tertulis Pejabat Pembina Kepegawaian dimana Pegawai Negeri Sipil yang bersangkutan bekerja untuk meminta persetujuannya.

2) Apabila Pejabat Pembina Kepegawaian instansi Pegawai Negeri Sipil yang bersangkutan bekerja menyetujui, maka Pejabat Pembina Kepegawaian tersebut membuat surat pernyataan persetujuan.

3) Surat pernyataan persetujuan tersebut dibuat rangkap 2 (dua) dan disampaikan kepada :

a) Pejabat Pembinaan Kepegawaian Instansi yang membutuhkan dan

b) Pegawai Negeri Sipil yang bersangkutan

4) Berdasarkan penyataan persetujuan tersebut, maka Pejabat Pembina Kepegawaian yang membutuhkan,

19 Peraturan Pemerintah Nomor 9 Tahun 2003 tentang Wewenang Pengangkatan, Pemindahan dan Pemberhentian Pegawai Negeri Sipil, Pasal 17 ayat (2) menyampaikan usul pemindahan antar instansi, kepada :
a) Kepala Badan Kepegawaian Negara untuk mendapat penetapan pemindahan :

(1)Antar Departemen/Lembaga

(2)Antara

Provinsi/Kabupaten/Kota dan Departemen/Lembaga

(3)Antar Daerah Provinsi

(4)Antara Daerah Kabupaten / Kota dan Daerah Kabupaten/Kota Provinsi lainnya

b) Pejabat Pembina Kepegawaian Daerah Provinsi untuk mendapat penetapan pemindahan
(1)Antar Kabupaten/Kota dalam satu Provinsi dan
(2)Antara Kabupaten/Kota dan Daerah Provinsi

5) Dalam pengajuan usul sebagaimana dimaksud angka 4), dilampirkan

a) Surat permintaan persetujuan

b) Surat pernyataan persetujuan pindah

c) Salinan/Fotocopi sah keputusan dalam pangkat terakhir

6) Berdasarkan usul tersebut, Kepala Badan Kepegawaian Negara atau Pejabat Pembinan Kepegawaian Daerah Provinsi menetapkan surat keputusan pemindahan antar instansi Pegawai Negeri Sipil yang bersangkutan

7) Surat Keputusan pemindahan tersebut dibuat sekurang-kurangnya dalam rangkap 5 (lima) disampaikan kepada

a) Pejabat Pembina Kepegawaian Instansi yang membutuhkan

b) Pejabat Pembina Kepegawaian Instansi asal

c) Pegawai Negeri Sipil yang bersangkutan

d) Kepala Kantor Perbendaharaan dan Kas Negara/Kas Daerah dan 
e) Kepala Badan Kepegawaian Negara/Kepala Kantor Regional Badan Kepegawaian Negara.

8) Berdasarkan surat keputusan pemindahan tersebut, maka :

a) Pejabat Pembina Kepegawaian Instansi yang membutuhkan Pegawai Negeri Sipil, menetapkan surat keputusan penempatan/pengangkatan dalam jabatan.

b) Pejabat Pembina Kepegawaian Instansi asal menetapkan surat keputusan pemberhentian dari jabatan/pekerjaannya, bukan surat keputusan pemberhentian sebagai Pegawai Negeri Sipil.

\section{9) Keputusan penempatan} pengangkatan dalam jabatan oleh Pejabat Pembina kepegawaian yang membutuhkan dan keputusan pemberhentian dari jabatan oleh Pejabat Pembina Kepegawaian instansi asal sebagaimana tersebut dalam angka 8), hendaknya dilakukan dalam waktu yang bersamaan, jangan terlampau lama perbedaan waktunya

10) Untuk tidak menimbulkan kekosongan atau keterlambatan dalam pembayaran gaji Pegawai Negeri Sipil yang bersangkutan, maka harus segera diselesaikan Surat Keterangan Penghentian Pembayaran (SKPP), apabila perpindahan antar instansi tersebut mengakibatkan perpindahan wilayah pembayaran. Apabila perpindahan instansi tersebut tidak mengakibatkan perpindahan wilayah pembayaran, maka harus dilakukan koordinasi dengan Kepala Kantor Perbendaharaan dan Kas negara yang bersangkutan.

Majelis Hakim berkesimpulan bahwa terhadap proses penetapan Pemindahan Penggugat dari Pemerintah Kabupaten Maluku Barat Daya di Tiakur ke Pemerintah Provinsi Maluku di Ambon tidak didasarkan atas permintaan ataupun permintaan persetujuan secara tertulis kepada Pejabat Pembina Kepegawaian dimana Pegawai Negeri Sipil yang bersangkutan bekerja sehingga tindakan Tergugat tersebut secara yuridis dinilai telah mengabaikan ketentuan Pasal 17 ayat (2) Peraturan Pemerintah Nomor 9 tahun 2003 tentang Wewenang Pengangkatan Pemindahan, Dan Pemberhentian Pegawai Negri Sipil dan Keputusan Kepala Badan Kepegawaian Negara Nomor 13 Tahun 2003 Tentang Petunjuk Teknis Pelaksanaan Peraturan Pemerintah Nomor 9 Tahun 2003 Tentang Wewenang Pengangkatan Pemindahan, Dan Pemberhentian Pegawai Negri Sipil. Fakta-fakta hukum tetap yang terungkap dalam persidangan, ternyata Penggugat dipindahkan dari Pemerintah Kabupaten Maluku Barat Daya di Tiakur ke Pemerintah Provinsi Maluku di Ambon tanpa jabatan dan mencermati bukti Penggugat maupun Tergugat, maka mutasi/pemindahan Penggugat yang sebelumnya dengan jabatan struktural Eselon II.A berdasarkan bukti Penggugat, menurut Majelis Hakim harus mengacu pada Keputusan Kepala Badan Kepegawaian Negara Nomor 13 Tahun 2002 Tentang Ketentuan Pelaksanaan Peraturan Pemerintah Nomor : 100 Tahun 2000 Tentang Pengangkatan Pegawai Negeri Sipil dalam Jabatan Struktural sebagaimana diubah dengan Peraturan Pemerintah Nomor 13 Tahun 2002, khususnya Bab II huruf $\mathrm{C}$ angka 7 dan angka 9 maka Perpindahan jabatan dapat dilakukan secara :

a. Horizontal yaitu perpindahan jabatan struktural dalam eselon yang sama

20 Keputusan Kepala Badan Kepegawaian Negara Nomor 13 Tahun 2002 Tentang Ketentuan Pelaksanaan Peraturan Pemerintah Nomor : 100 Tahun 2000 Tentang Pengangkatan Pegawai Negeri Sipil dalam Jabatan Struktural sebagaimana diubah dengan Peraturan Pemerintah Nomor 13 Tahun 2002, khususnya Bab II huruf $\mathrm{C}$ angka 7 
b. Vertikal yaitu perpindahan dari eselon yang lebih rendah ke eselon yang lebih tinggi

c. Diagonal yaitu perpindahan dari :

1) Jabatan struktural ke dalam jabatan fungsional;

2) Jabatan fungsional ke dalam jabatan struktural;

Angka 9 : Untuk menjamin pembinaan karier yang sehat, pada prinsipnya tidak diperbolehkan perpindahan jabatan struktural dari eselon yang lebih tinggi ke dalam eselon yang lebih rendah, seperti Kepala Dinas (eselon IIb) dipindahkan dan diangkat menjadi Kepala Sub Dinas pada Kabupaten/Kota (eselon IIIa) .

Ketentuan hukum tersebut dikaitkan dengan fakta hukum di atas, maka perpindahan antar instansi atas Penggugat justru bertentangan dan mengabaikan ketentuan mengenai prinsip mutasi atau perpindahan jabatan struktural sebagaimana diatur dalam Keputusan Kepala Badan Kepegawaian Negara Nomor : 13 Tahun 2002, Bab II huruf $\mathrm{C}$ angka 7 dan angka 9. Sesuai dengan ketentuan Pasal 14 ayat (1) dan ayat (4) Peraturan Pemerintah Nomor : 100 Tahun 2000 Tentang Pengangkatan Pegawai Negeri Sipil dalam Jabatan Struktural sebagaimana diubah dengan Peraturan Pemerintah Nomor 13 Tahun 2002 dinyatakan bahwa :

Ayat (1) : Untuk menjamin kualitas dan obyektifitas dalam pengangkatan, pemindahan dan pemberhentian Pegawai Negeri Sipil dalam dan dari jabatan struktural Eselon II ke bawah di setiap instansi dibentuk Badan Pertimbangan Jabatan dan Kepangkatan, selanjutnya disebut Baperjakat

Ayat (4) : Tugas pokok Baperjakat Instansi Pusat dan Baperjakat Instansi Daerah Propinsi/Kabupaten/Kota memberikan pertimbangan kepada Pejabat Pembina Kepegawaian Pusat dan Pejabat Pembina Kepegawaian Daerah
Propinsi/Kabupaten/Kota dalam pengangkatan, pemindahan dan pemberhentian dalam dan dari jabatan struktural Eselon II ke bawah.

Menurut Nirahua Salmon Eliazer Marthen sebagai ahli dalam persidangan menerangkan pada pokoknya setiap pengangkatan, pemindahan dan pemberhentian Pegawai Negeri Sipil dalam dan dari jabatan struktural Eselon II ke bawah haruslah melalui pertimbangan Baperjakat ${ }^{21}$. Selanjutnya dalam Keputusan Kepala Badan Kepegawaian Negara Nomor 13 Tahun 2002 Tentang Ketentuan Pelaksanaan Peraturan Pemerintah Nomor : 100 Tahun 2000 Tentang Pengangkatan Pegawai Negeri Sipil dalam Jabatan Struktural sebagaimana diubah dengan Peraturan Pemerintah Nomor 13 Tahun 2002 khususnya pada huruf $\mathrm{C}$ Perpindahan angka 10 huruf c. yang mengatur bahwa "Sebelum Pimpinan Instansi penerima menghubungi Pimpinan Instansi asal, terlebih dahulu harus mendapat pertimbangan dari Baperjakat

Majelis Hakim berpendapat bahwa Tergugat dalam menerbitkan obyek sengketa tidak melalui prosedur pertimbangan Baperjakat sebagaimana disyaratkan dalam ketentuan Pasal 14 ayat (1) dan ayat (4) Peraturan Pemerintah Nomor : 100 Tahun 2000 Tentang Pengangkatan Pegawai Negeri Sipil dalam Jabatan Struktural sebagaimana diubah dengan Peraturan Pemerintah Nomor 13 Tahun 2002 dan Keputusan Kepala Badan Kepegawaian Negara No. 13 Tahun 2002 Tentang Ketentuan Pelaksanaan Peraturan Pemerintah Nomor : 100 Tahun 2000 Tentang Pengangkatan Pegawai Negeri Sipil dalam Jabatan Struktural sebagaimana diubah dengan Peraturan Pemerintah Nomor 13 Tahun 2002 khususnya pada huruf C. Perpindahan

21 Nirahua Salmon Eliazer Marthen, Ahli Hukum Administrasi Negara Dalam Perkara Nomor 23/G/2014/PTUN.ABN di Pengadilan Tata Usaha Negara Ambon 
angka 10 huruf c. ${ }^{22}$ Selanjutnya keterangan saksi Tergugat di persidangan atas nama Maritje Lopulalan, selaku Kepala Badan Kepegawaian Daerah Provinsi Maluku yang pada pokoknya menyatakan Tergugat telah merencanakan dan menjanjikan jabatan Penggugat di Pemerintah Provinsi Maluku sebagai Widyaiswara yang menurutnya setara dengan Jabatan Penggugat sebelumnya yaitu Eselon II.a, menurut Majelis Hakim oleh karena terhadap jabatan tersebut belum ada bukti tertulis atau dibuat dalam bentuk Keputusan dan masih berupa rencana atau janji.

Aspek prosedur penerbitan objek sengketa berupa Surat Keputusan Gubernur Maluku Nomor : 125.a Tahun 2014 tanggal 20 Mei 2014 tentang Pemindahan Pegawai Negeri Sipil atas nama Sdr. Kapressy Charles, SH, M.Si NIP.19560911 $198603 \quad 1 \quad 009$ Pembina Utama Madaya (IV/d) dari Pemerintah Kabupaten Maluku Barat Daya di Tiakur ke Pemerintah Provinsi Maluku di Ambon telah bertentangan dengan ketentuan peraturan perundang-undangan yang berlaku .

Berdasarkan pengujian peraturan perundang-undangan yang berlaku secara mutatis mutandis juga dijadikan dasar dalam pengujian objek sengketa a quo berdasarkan Asas-Asas Umum Pernerintahan Yang Baik. Oleh karena terbukti menurut hukumnya penerbitan objek sengketa $a$ quo adalah cacat hukum secara prosedural, sehingga adil dan beralasan hukum apabila tuntutan Penggugat supaya keputusan objek sengketa dinyatakan batal beralasan hukum untuk dikabulkan dan Tergugat diwajibkan untuk mencabutnya. Oleh karena objek sengketa telah dinyatakan batal dan diwajibkan dicabut, maka kepada Tergugat harus pula diwajibkan untuk merehabilitasi Penggugat dalam

22 Pertimbangan Putusan Majelis Hakim Pengadilan Tata Usaha Negara Ambon Dalam Perkara Nomor 23/G/2014/PTUN.ABN, h, 34 kedudukan, harkat, martabat serta hak-haknya sebagai Sekretaris Daerah Kabupaten Maluku Barat Daya termasuk tunjangan jabatan yang sah menurut peraturan perundang-undangan yang berlaku sejumlah Rp. 3. 250.000,- (Tiga juta dua ratus lima puluh ribu rupiah) yang dihitung sejak tidak diterimanya tunjangan dimaksud, jumlah mana akan bertambah terus sampai dilaksanakannya putusan yang telah berkekuatan hukum tetap dalam perkara a quo.

Penetapan Penundaan Majelis Hakim Pengadilan Tata Usaha Negara Ambon Nomor : 23/G/2014/PTUN.ABN, tanggal 21 Juli 2014 mengenai Penundaan pelaksanaan dan tindak lanjut Keputusan Tata Usaha Negara berupa Surat Keputusan Gubernur Maluku Nomor : 125. a Tahun 2014, tanggal 20 Mei 2014 tentang Pemindahan Pegawai Negeri Sipil atas nama Kapressy Charles, SH, M.Si, NIP : 195609111986031009 Pembina Utama Madya (IV/d) dari Pemerintah Kabupaten Maluku Barat Daya di Tiakur ke Pemerintah Provinsi Maluku di Ambon, yang telah dikeluarkan oleh Majelis Hakim yang memeriksa perkara a quo haruslah dikuatkan dan dipertahankan serta dinyatakan tetap berlaku. Oleh karena gugatan Penggugat dikabulkan seluruhnya maka Tergugat sebagai pihak yang kalah sesuai dengan ketentuan Pasal 110 Undang-Undang Nomor 5 Tahun 1986 Tentang Peradilan Tata Usaha Negara harus dihukum untuk membayar biaya perkara yang besarnya akan ditetapkan dalam amar Putusan ini. ${ }^{23}$ Mengenai alat-alat bukti yang diajukan para pihak yang tidak/belum dijadikan bahan pertimbangan dalam Putusan ini, menurut penilaian Majelis Hakim tidak perlu dipertimbangkan lagi karena dengan alat-alat bukti yang telah dipertimbangkan sudah cukup bagi Majelis Hakim untuk menjatuhkan suatu Putusan, akan tetapi tetap dilampirkan

23 Undang-Undang Nomor 5 Tahun 1986 Tentang Peradilan Tata Usaha Negara, Pasal 110 
dan menjadi satu kesatuan dalam sengketa ini.

Mengingat, Undang-Undang Nomor 5 Tahun 1986 Tentang Peradilan Tata Usaha Negara sebagaimana telah diubah dengan Undang-Undang Nomor 9 Tahun 2004 dan Undang-Undang Nomor 51 Tahun 2009, serta peraturan perundang-undangan yang berkaitan dengan perkara ini $\quad:^{24}$

\section{EN G A D I L I}

Dalam Penundaan : Menguatkan Penetapan Penundaan Majelis Hakim Pengadilan Tata Usaha Negara Ambon Nomor : 23/G/2014/PTUN.ABN tanggal 21 Juli 2014 mengenai Penundaan pelaksanaan dan tindak lanjut Keputusan Tata Usaha Negara berupa Surat Keputusan Gubernur Maluku Nomor : 125. a Tahun 2014, tanggal 20 Mei 2014 tentang Pemindahan Pegawai Negeri Sipil atas nama KAPRESSY CHARLES, SH, M.Si, NIP : 195609111986031009 Pembina Utama Madya (IV/d) dari Pemerintah Kabupaten Maluku Barat Daya di Tiakur ke Pemerintah Provinsi Maluku di Ambon

Dalam Pokok Sengketa :

1. Mengabulkan gugatan Penggugat untuk seluruhnya

2. Menyatakan batal Keputusan Tata Usaha Negara yang diterbitkan oleh Tergugat berupa Surat Keputusan Gubernur Maluku Nomor : 125.a Tahun 2014 tanggal 20 Mei 2014 tentang Pemindahan Pegawai Negeri Sipil atas nama Sdr. KAPRESSY CHARLES, SH, M.Si NIP.19560911 1986031009 Pembina Utama Madaya (IV/d) dari Pemerintah Kabupaten Maluku Barat Daya di Tiakur ke Pemerintah Provinsi Maluku di Ambon

3. Mewajibkan Tergugat untuk mencabut Keputusan Tata Usaha

24 Putusan Majelis Hakim Pengadilan Tata Usaha Negara Ambon Dalam Perkara Nomor 23/G/2014/PTUN.ABN
Negara yang diterbitkan oleh Tergugat berupa Surat Keputusan Gubernur Maluku Nomor : 125.a Tahun 2014 tanggal 20 Mei 2014 tentang Pemindahan Pegawai Negeri Sipil atas nama Sdr. KAPRESSY CHARLES, SH, M.Si NIP.19560911 1986031009 Pembina Utama Madya (IV/d) dari Pemerintah Kabupaten Maluku Barat Daya di Tiakur ke Pemerintah Provinsi Maluku di Ambon

4. Mewajibkan Tergugat untuk merehabilitasi Penggugat dalam kedudukan, harkat, martabat serta hak-haknya sebagai Sekretaris Daerah Kabupaten Maluku Barat Daya termasuk tunjangan jabatan yang sah menurut peraturan perundang-undangan yang berlaku sejumlah Rp. 3.250.000,- (Tiga juta dua ratus lima puluh ribu rupiah) yang dihitung sejak tidak diterimanya tunjangan dimaksud, jumlah mana akan bertambah terus sampai dilaksanakannya putusan yang telah berkekuatan hukum tetap dalam perkara a quo;

5. Menghukum Tergugat untuk membayar biaya yang timbul dalam sengketa ini sebesar Rp. 297.000,(Dua ratus sembilan puluh tujuh ribu rupiah).

\section{P E N U T U P}

Penundaan Keputusan Tata Usaha Negara yang menjadi obyek sengketa dapat dikabulkan, oleh karena masih adanya tindakan faktual yang berlanjut yang harus dilakukan, yaitu Pengangkatan Sekretaris Daerah yang defenitif, pelantikan ataupun serah terima jabatan dari Sekretaris Daerah yang diberhentikan kepada Sekretaris Daerah yang diangkat yang isinya sebagai suatu pernyataan (deklaratur) penyerahan segala tugas, wewenang dan kewajiban.

Pelanggaran terhadap Penetapan ini akan menjadi tanggung jawab 
sepenuhnya baik secara yuridis maupun administratif terhadap pihak yang melanggarnya. Mengingat ketentuan dalam Undang-Undang Nomor 5 Tahun 1986 Tentang Peradilan Tata Usaha Negara sebagaimana telah dirubah oleh Undang-Undang Nomor 9 Tahun 2004 dan Undang-Undang Nomor 51 Tahun 2009 serta ketentuan hukum lain dengan keputusan penetapan yaitu mengabulkan permohonan Penundaan Penggugat dan Memerintahkan kepada Tergugat untuk menunda pelaksanaan dan tindak lanjut Keputusan Tata Usaha Negara berupa Surat Keputusan Gubernur Maluku Nomor : 125. a Tahun 2014, tanggal 20 Mei 2014 tentang Pemindahan Pegawai Negeri Sipil atas nama Kapressy Charles, SH, M.Si, NIP : 195609111986031009 Pembina Utama Madya (IV/d) dari Pemerintah Kabupaten Maluku Barat Daya di Tiakur ke Pemerintah Provinsi Maluku di Ambon, sampai putusan sengketa ini mempunyai kekuatan hukum tetap, kecuali ada Penetapan lain yang menyatakan sebaliknya

\section{DAFTAR PUSTAKA}

Dani Elpah, 2011, Penundaan Pelaksanaan Keputusan Tata Usaha Negara, disampaikan pada Pelatihan Hakim Peradilan Tata Usaha Negara, Diklat Kumdil MA RI, Megamendung.

H.L.A. Hart, 2009, Konsep Hukum (The Concept Of Law), Penerjemah M. Khoizin, Nusa Media, Bandung.

Marbun S. F, 2003, Peradilan Hukum Administrasi dan Upaya Administrasi di Indonesia, UII-Press, Jogjakarta.

Sjahran Basah, 2002, Perlindungan Hukum terhadap sikap-tindak Administrasi Negara, cetakan II, Alumni, Bandung.

Soemaryo, 2009, Tuntunan Praktek Beracara Di Peradilan Tata Usaha Negara, Primamedia Pustaka,
Jakarta.

Supandi, 2002, Ganti Rugi Akibat Tindakan Pejabat Pemerintah Dalam RUU Administrasi Pemerintahan Dan Prospek Peradilan Tata Usaha Negara, PT. Sofemdia, Medan.

\section{Peraturan Perundang-Undangan}

Undang-Undang Nomor 5 Tahun 1986 tentang Peradilan Tata Usaha Negara

Undang-Undang Nomor 9 Tahun 2004 tentang Perubahan atas Undang-Undang Nomor 5 Tahun 1986 tentang Peradilan Tata Usaha Negara

Undang-Undang Nomor 51 Tahun 2009 tentang Perubahan Kedua atas Undang-Undang Nomor 5 Tahun 1986 tentang Peradilan Tata Usaha Negara.

Undang Undang Nomor 5 Tahun 2014 tentang Aparatur Sipil Negara.

Peraturan Pemerintah Nomor 9 Tahun 2003 tentang Wewenang Pengangkatan, Pemindahan dan Pemberhentian Pegawai Negeri Sipil.

Peraturan Presiden Republik Indonesia Nomor 26 Tahun 2007 Tentang Tunjangan Jabatan Struktural.

Peraturan Pemerintah RI Nomor 53 Tahun 2010 Tentang Disiplin Pegawai Negeri Sipil.

Keputusan Menteri Dalam Negeri Nomor 16 Tahun 2003 Tentang Tata Cara Konsultasi Pengangkatan dan Pemberhentian Sekretaris Daerah Provinsi, Sekretaris Daerah Kabupaten / Kota Serta Pejabat Struktural Eselon II di Lingkungan Pemerintah Kabupaten Kota, BAB IV tentang Pemberhentian

Surat Edaran Mahkamah Agung Republik Indonesia Nomor 2 Tahun 1991 Tentang Petunjuk Pelaksanaan Beberapa Ketentuan Dalam Undang-Undang Nomor 5 Tahun 
1986 Tentang Peradilan Tata Usaha Negara

Surat Menteri Pendayagunaan Aparatur Negara tanggal 29 Mei 1991 Nomor : B-47/I/1991 perihal pelaksanaan putusan Pengadilan Tata Usaha Negara yang ditujukan kepada para Pejabat Tinggi Negara, antara lain kepada para Gubernur seluruh Indonesia.

Surat Menteri Pendayagunaan Aparatur Negara tanggal 28 Agustus 2004 Nomor : SE/24/M.PAN/8/2004 Perihal Pelaksanaan Putusan Pengadilan Tata Usaha Negara.

\section{Lain Lain}

Irfan Fachruddin, Pelaksanaan Putusan Peradilan Tata Usaha Negara Makalah. Disampaikan pada Rakerda Mahkamah Agung Republik Indonesia Bidang Peradilan Tata Usaha Negara Wilayah Sumatera, pada tanggal 2 November 2009 di Medan.

Nirahua Salmon Eliazer Marthen, Ahli Hukum Administrasi Negara Dalam Perkara Nomor 23/G/2014/PTUN.ABN di Pengadilan Tata Usaha Negara Ambon.

Pertimbangan Penetapan Penundaan Majelis Hakim Pengadilan Tata Usaha Negara Dalam Perkara Nomor 23/G/2014/PTUN.ABN.

Pertimbangan Putusan Majelis Hakim Pengadilan Tata Usaha Negara Ambon Dalam Perkara Nomor 23/G/2014/PTUN.ABN.

Putusan Penetapan Penundaan Majelis Hakim Pengadilan Tata Usaha Negara Ambon Dalam Perkara Nomor 23/G/2014/PTUN.ABN.

Putusan Majelis Hakim Pengadilan Tata Usaha Negara Ambon Dalam Perkara Nomor 23/G/2014/PTUN.ABN.

Surat Persetujuan Pengangkatan Calon Sekretaris Daerah Kabupaten
Maluku Barat Daya dari Menteri Dalam Negeri Nomor : $\mathrm{X} .133 .81 / 176 / \mathrm{S} 1$ tanggal 3 Desember 2008.

Surat Keputusan Gubernur Maluku Nomor : 821.4 / 3478 / M tertanggal 19 Desember 2008 tentang Pengangkatan Sekretaris Daerah Kabupaten Maluku Barat Daya.

Surat Keputusan Gubernur Maluku Nomor : 821.4 / 3478 / M tertanggal 19 Desember 2008 tentang persetujuan Menteri Dalam Negeri sesuai Surat Persetujuan Pengangkatan Calon Sekretaris Daerah Kabupaten Maluku Barat Daya Nomor : X.133.81/176/S1 tanggal 3 Desember 2008.

Keputusan Bupati Maluku Barat Daya Nomor : 800-204 Tahun 2011, tanggal 06 September 2011 Tentang Perpanjangan Pertama Kali Batas Usia Pensiun (BUP) Pegawai Negeri Sipil Di Lingkungan Pemerintah Daerah Maluku Barat Daya.

Surat Bupati Maluku Barat Daya Nomor : 005/11/2014, tanggal 18 April 2014 perihal Mutasi yang ditujukan kepada Gubernur Provinsi Maluku.

Surat Keputusan Gubernur Maluku Nomor : 125.a Tahun 2014 tanggal 20 Mei 2014 tentang Pemindahan Pegawai Negeri Sipil, atas nama Kapressy Charles, SH. Msi, NIP : $19560911 \quad 198603 \quad 1009$ dari Kabupaten Maluku Barat Daya di Tiakur ke Pemerintah Povinsi Maluku di Ambon.

Surat Keputusan Nomor : 821.2-45 tanggal 26 Mei 2014 tentang Pengangkatan Joseph Domlay menjadi Pejabat Sementara menggantikan Kapressy Charles.

Surat Panggilan I Nomor : W4-TUN3/532/H.01.03/VI/2014, tanggal 25 Juni 2014, Sebagai Pihak Ketiga Dalam Perkara Nomor 
23/G/2014/PTUN.ABN

di

Pengadilan Tata Usaha Negara

Ambon.

Surat Panggilan II Nomor : W4-TUN3/595/H.01.03/VII/2014, tanggal 07 Juli 2014, Sebagai Pihak Ketiga Dalam Perkara Nomor Nomor 23/G/2014/PTUN.ABN di Pengadilan Tata Usaha Negara Ambon.

Surat Panggilan III Nomor : W4-TUN3/616/H.01.03/VII/2014, tanggal 14 Juli 2014, Sebagai Pihak Ketiga Dalam Perkara Nomor Nomor 23/G/2014/PTUN.ABN di Pengadilan Tata Usaha Negara Ambon.

Keputusan Kepala Badan Kepegawaian Negara Nomor 13 Tahun 2002 Tentang Ketentuan Pelaksanaan Peraturan Pemerintah Nomor : 100 Tahun 2000 Tentang Pengangkatan Pegawai Negeri Sipil dalam Jabatan Struktural sebagaimana diubah dengan Peraturan Pemerintah Nomor 13 Tahun 2002, khususnya Bab II huruf C angka 7. 